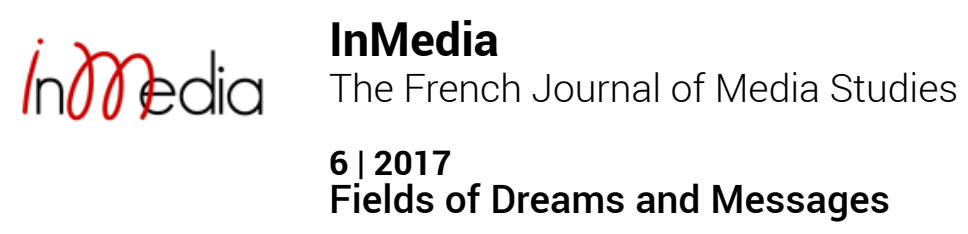

\title{
Barbie -Musée des Arts Décoratifs Paris
}

\author{
Anaïs Le Fèvre-Berthelot
}

\section{(2) OpenEdition \\ Journals}

Electronic version

URL: http://journals.openedition.org/inmedia/873

DOI: $10.4000 /$ inmedia. 873

ISSN: 2259-4728

\section{Publisher}

Center for Research on the English-Speaking World (CREW)

\section{Electronic reference}

Anaïs Le Fèvre-Berthelot, «Barbie -Musée des Arts Décoratifs Paris », InMedia [Online], 6 | 2017,

Online since 18 December 2017, connection on 24 September 2020. URL : http://

journals.openedition.org/inmedia/873; DOI : https://doi.org/10.4000/inmedia.873

This text was automatically generated on 24 September 2020

(c) InMedia 


\title{
Barbie -Musée des Arts Décoratifs Paris
}

\author{
Anaïs Le Fèvre-Berthelot
}

1 At the top of the grand staircase of the Musée des Arts Décoratifs, the pink wall set the tone. Once the visitors had passed the doors they entered a dark room and faced the enlarged projections of the latest fashion shots from Barbie's Instagram account (@barbiestyle). Indeed, "Barbie, ever up-to-date, uses new technologies to communicate with her fans and wins the hearts of new aficionados," the museum explained. ${ }^{1}$ This could have been the beginning of an exhibition questioning Barbie's socio-cultural meaning, her link with media franchises, the gender representations she has conveyed over the years, the marketing practices that are associated with the doll, but the museum apparently had other plans.

2 After a short historical display presenting the evolution of fashion dolls since the $18^{\text {th }}$ century, the exhibition focuses exclusively on Barbie: the genesis of the doll, her evolution, her career, her family and her love-life, the manufacturing process, her relationship with pop culture and the fashion world. In the various sections the information seems directly written by Mattel, even though the curator swears to the contrary. ${ }^{2}$ If the staff of the Museum is willing to take the blame for "explanations" such as "Barbie left Ken in 2004 for Blaine, an Australian surfer. In 2011, after an assiduous courtship, the newly revamped and modernized Ken managed to win Barbie back," one can only hope the price for their scientific integrity was high enough.

Barbie will turn sixty in 2019. The doll has been the target of many controversies as generations of girls played with this unrealistic model of femininity ${ }^{3}$ But neither this aspect, nor Mattel's plummeting sales in recent years were mentioned in the exhibition.

4 The exhibition housed by the Musée des Arts Décoratifs in Paris was meant to coincide with the worldwide launch of a new doll collection named "Fashionista" that includes "3 new silhouettes, 18 skin colors, 23 hair colors and 14 different faces". Barbie can now be "tall" (taller than she already was that is), "petite" (one head smaller than the classic Barbie), and -this is the real novelty- "curvy" (which means that if she was life-size, 
she would look like an average-size woman). In addition to the Paris exhibition, Barbie was also the star of an exhibition shown at the Mudec ${ }^{4}$ in Milan (October 28, 2015March 13, 2016) and the Vittoriano museum in Rome (April 15-October 30, 2016). Despite the need for a scientific analysis of Barbie as a social and cultural phenomenon, the Paris exhibition was simply a sophisticated element in a global marketing strategy. And it worked: Mattel's sales went up in 2016.

The exhibition reminded the visitors of the origins of Barbie. Created in 1959 by Ruth Handler, the doll was inspired-to say the least-by the Bild-Lilli doll. Lilli was originally a sassy cartoon character in the Bild-Zeitung and the 12-inch and 7.5-inch dolls were meant for men rather than for their children. When Barbie was first created, Mattel's executives and the toy industry professionals "seemed uncomfortable with the doll's breasts." Even though the exhibition (following Mattel) praises Barbie for her freedom and her ability to pursue the careers of her dreams, the gender politics of the toy is not questioned here. The exhibition shows three "Barbie for President" dolls: one in an 80s pantsuit, another one with a blue suit and short blond bob, and one who looks like a Miss America Prom Queen. Anything is possible as Mattel says.

Barbie's link with fashion and the association of the doll with a glamorous lifestyle was the main focus of the exhibition. Besides the Instagram shots adopting the visual codes of fashion blogging (selfies with friends, pictures of outfits and accessories, "throwback Thursday pictures" showing older models...), many rooms were devoted to Barbie's special relationships with famous fashion designers. A series of videos made with shoedesigner Christian Louboutin was on display, several runway shows were staged, and an impressive but pointless wall of tiny clothes organized by color adorned the last room of the exhibition.

7 Some artistic works inspired by Barbie are also on display, including the 1986 portrait of the doll by Warhol. The more subversive works of Mariel Clayton are mentioned in the exhibition catalog, but not displayed in the museum. ${ }^{5}$ Warhol's pop art portrait sums up the exhibition: it is smooth, pink, and the criticism can only be found in the eyes of the onlookers that do not succumb to the fascinating powers of the blond doll. A disturbing example of these powers is given in the documentary film Magical Universe (2014) about outsider artist Al Carbee who created dioramas and collages around Barbie dolls.

8 In addition to her recent status of social network it-girl, Barbie is the character of several animated TV series and of a number of films, and of course, she has been featured in a number of commercials. Even though the doll is at the center of a variety of media productions, the exhibition's presentation of audiovisual documents was often disappointing. The extract from Magical Universe for example was presented on a tiny screen, as were most videos in the exhibition. The curators did not find a coherent or efficient way to deal with sound nor with the translation of documents that, for the most part, were in English even though French children represented a large proportion of the visitors.

9 Between the section devoted to Barbie's family and friends and the one presenting her many careers, a small playroom for children was installed. Rather than presenting the Barbie Fan club paraphernalia as just another aspect of Barbie's wonderful world, it might have been interesting to question the series of inventions used by Mattel to track its young consumers, including the latest ones: the camera doll and the talking doll. ${ }^{6}$ There is no doubt that a Barbie exhibition has its place in the program of a museum 
devoted to design, advertising and fashion. There is no doubt that Barbie is a major socio-cultural phenomenon that has had tremendous influence over generations of girls and that should be analyzed as such. If nothing else, the display at the Musée des Arts décoratifs had the advantage of pointing to the need for such work to be done with rigor and independence.

In the end, Barbie fans may have enjoyed going down memory lane, while visitors who actually hoped to learn something certainly went home disappointed. A detour by the museum gift store only corroborated what the cynics knew all along: everything can be bought. One can only regret that the lack of public funding leads major cultural institutions to house events that really should be organized in the reception hall of Mattel with complimentary drinks instead of an eleven-euro entrance ticket.

Musée des arts décoratifs, 107 rue de Rivoli, 75001 Paris.

March 10, 2016 -September 18, 2016

Further information

\section{ENDNOTES}

1. Unless specified otherwise, the quotes are taken from the exhibition material.

2. Doreen carvajal, "With Museum Shows in Europe, Barbie Gets Her Moment With the Masters", The New York Times, March 11, 2016. Accessed 10/10/16.

3. Karlie Rice, Ivanka Prichard, Marika Tiggemann \& Amy Slater, "Exposure to Barbie: Effects on thin-ideal internalisation, body esteem, and body dissatisfaction among young girls," Body Image, December 2016, vol. 19, pp. 142-149.

4. Museo delle Culture

5. Anne Monier (dir.), Barbie [exhibition catalogue, Paris, Musée des Arts décoratifs, March 10 -September18 2016], Paris, France, Musée des Arts décoratifs, 2016.

6. “'FBI: New Barbie 'Video Girl' doll could be used for child porn'", CNN.com, December 4, 2010, accessed 03/06/2017.

\section{AUTHOR}

\section{ANAÏS LE FÈVRE-BERTHELOT}

Anaïs Le Fèvre-Berthelot is associate professor of American Studies at University Rennes 2 